\title{
Effect of different human tissue processing techniques on SARS-CoV-2 inactivation-review
}

\author{
André Oliveira Paggiaro (i) V Viviane Fernandes Carvalho (i) Rolf Gemperli $(\mathbb{C}$
}

Received: 2 July 2020/Accepted: 25 September 2020/Published online: 8 October 2020

(C) Springer Nature B.V. 2020

\begin{abstract}
The safety of the tissue transplant recipient is a top priority for tissue banks, and the emergence of the new coronavirus SARS-CoV-2 has raised significant concerns about the risks of releasing tissue for clinical use. In the present study, we conducted a literature review about the potential infectivity of SARS-CoV-2 in different biological tissues and the influence of various tissue processing and sterilization procedures on viral inactivation. The search revealed that SARS-CoV-2 binds to the human angiotensinconverting enzyme receptor to penetrate human cells. These receptors are present in skin cells, musculoskeletal tissue, amniotic membranes, cardiovascular tissue and ocular tissues, including the cornea. In general, we found that coronaviruses are stable at low temperatures, and inactivated upon exposure to extreme heat and $\mathrm{pH}$. Notably, gamma irradiation,
\end{abstract}

A. O. Paggiaro ( $₫)$

ICHC Tissue Bank-HCFMUSP, Eneas de Carvalho,

São Paulo 05403-000, Brazil

e-mail: andre.paggiaro@hc.fm.usp.br;

andrepaggiaro@yahoo.com.br

A. O. Paggiaro · R. Gemperli

Plastic Surgery Department-HCFMUSP, Universidade de

São Paulo, São Paulo 07023-070, Brazil

e-mail: rolf.gemperli@hc.fm.usp.br

A. O. Paggiaro · V. F. Carvalho

Nursing Post Graduation-Universidade Guarulhos,

Guarulhos 05403-000, Brazil

e-mail: vcarvalho@prof.ung.br which has already been employed to inactivate SARS and MERS, could be useful for sterilizing skin, amnion and musculoskeletal tissues against SARSCoV-2. We conclude that due to the limited information about the effects of physical and chemical tissue processing methods on viral neutralization, rigorous donor screening is still essential for tissue transplant recipient safety.

Keywords Covid-19 - Infections · Patient safety · Tissue transplantation - Virus inactivation

\section{Introduction}

On January 11st, 2020, the authorities in China confirmed the existence of 200 human cases and three deaths caused by a new type of coronavirus (CoV), now known as Severe Acute Respiratory Syndrome Coronavirus 2 (SARS-CoV-2), that leads to the development of Coronavirus Disease 2019 (COVID19) (Chang et al. 2020). Symptoms of COVID-19 include mild flu-like symptoms such as cough, fever, fatigue, headache. However, in more severe cases, it can cause pneumonia, characterized by the image of ground glass on the chest tomography, and can progress to acute respiratory distress syndrome, acute heart injury, secondary infections and even death (Wu et al. 2020a, b). 
On March 11st, the World Health Organization declared COVID-19 to be a worldwide pandemic, and today, more than 2 million people have been infected (Lauer et al. 2020). Unfortunately, because of the rapid transmissibility of the virus (Chen 2020) and current lack of scientific knowledge about this new pathogen, healthcare providers and services have had to make decisions without complete knowledge about what we face (Weston and Frieman 2020).

For example, it has been recommended that blood banks measure the temperatures of the donors and ask questions about possible COVID-19 exposure and/or trips to areas of community transmission. In some cases, the banks contact the donors afterward to ask about their current health status. These extra layers of security are due to the presence of viral RNA in the plasma after just 2-3 days of symptom onset and because the viral load in donors during the incubation period, as well as in asymptomatic individuals, are still unknown. Recently, blood banks have started studying the effects of viral inactivation methods, commonly used on blood products, for coronavirus destruction (Chang et al. 2020).

Even though some tissues can be replaced by alloplastic materials and, in most cases, the transplant does not involve an imminent risk of death, allowing it to be postponed; the risk assessment for tissue transplantation still needs to be rigorous. Along these lines, SARS-CoV-2 has become a new challenge for quality management systems (Ashford 2010), and the tissue banks must certify the safety and traceability of the tissue supplied, to guarantee quality control. However, it is not known if the virus can infect tissues or if processing and sterilization tissue methods could be employed to inactivate it.

Due to the short amount of time SARS-CoV-2 has been present in the population, there is still a lack of knowledge about which human cells and tissues are infected by this virus. Even with tissue banks adopting more stringent donor screening measures, the existence of a large number of asymptomatic or oligosymptomatic patients further complicates donor selection (Yu and Yang 2020). Additionally, the circulation time of the virus within the community increases the risk of tissue contamination. For example, a recent Italian study showed that the virus was circulating throughout the country a few weeks before the first case was identified (Zehender et al. 2020). Thus, it is plausible that the tissue banks could collect and store contaminated material in their stock before the first case is reported in their community.

In the face of so many uncertainties and risks, we conducted a literature review to assess the existing knowledge about the risk of different types of human tissues being contaminated by SARS-CoV-2 and to evaluate the potential effectiveness of various tissue preservation and sterilization techniques on coronavirus inactivation, especially SARS-CoV-2.

\section{Methods}

The PUBMED/Medline and EMBASE databases were searched, using the following MeSH terms: "COVID10 " and "SARS-CoV-2"; as related to "virus inactivation"; "ionizing radiation"; "heat"; "freezing"; "freeze drying"; "glycerol"; "sterilization"; "refrigeration"; "tissue transplantation"; "disinfectants"; "transplantation"; "bone"; "musculoskeletal tissue"; "skin"; "heart valve" "amnion"; "cornea" and "eye". However, since this epidemic began relatively recently, few scientific articles address SARS-CoV-2 inactivation. Therefore, we decided to expand the search to include the MeSH term "Coronavirus", along with the previously mentioned terms. This expanded search identified previous studies about techniques employed to inactivate other Coronaviradae family viruses.

To identify article related to SARS-CoV-2 transmission by tissue or organ transplantation, we used the MeSH terms: "Covid-19" or "SARS-CoV-2" and "tissue transplantation"; "organ transplantation"; "liver transplantation"; "kidney transplantation"; "lung transplantation"; "kidney transplantation"; "bone transplantation"; "musculoskeletal transplantation"; "skin transplantation"; "amnion transplantation"; "heart valve transplantation"; "eye transplantation" and "cornea transplantation".

Herein, we sought to address three main topics: the structure of the SARS-CoV-2 virus, the infectivity of SARS-CoV-2 in human tissues and reports of transmission following tissue and organ transplantation, and the effect of tissue preservation and sterilization techniques on viral inactivation. 


\section{Results and discussion}

\section{SARS-CoV-2 structure}

It is well-known that CoVs are enveloped, positivesense, single-stranded RNA viruses that are subdivided into four groups (alpha-, beta-, gamma- and delta-CoV). In general, CoVs typically infect the respiratory and digestive tracts of birds and mammals (Cong et al. 2017). Seven of the CoV subtypes, belonging to the alpha and beta groups, have been shown to infect humans. Four of these seven, HCoV229E, HCoV-OC43, HCoV-NL63 and HCoV-HKU1, can cause self-limited upper respiratory disease (Chang et al. 2020) and the other three, Severe Acute Respiratory Syndrome coronavirus (SARS-CoV), Middle East Respiratory Syndrome coronavirus (MERS-CoV) and SARS-CoV-2, are highly pathogenic and can cause severe pneumonia and respiratory failure (Du et al. 2020).

In general, the CoVs are composed of four essential structural proteins: spike (S), membrane (M), envelope (E) and nucleocapsid (N). It has been shown that the $\mathrm{S}$ protein is responsible for attachment and entry into the target cells, thus playing a fundamental role in the cellular and humoral responses to the virus (Nie et al. 2020). It should be pointed out that SARS-CoV and SARS-CoV-2 share $80 \%$ identity at the nucleotide level (Weston and Frieman 2020). In SARS-CoV-2, the C-terminal domain of the $\mathrm{S}$ protein binds to the human angiotensin-converting enzyme 2 (hACE2) present in the cell membrane and is taken up into the cell. While this occurs through a mechanism similar to that of SARS-CoV, the S protein binds with higher affinity, which may account for the enhanced transmissibility of the new virus (Wang et al. 2020).

Previous reports have demonstrated that $\mathrm{CoVs}$ are often vulnerable to acidic and basic $\mathrm{pH}$ values and heat (Lamarre and Talbot 1989; Rabenau et al. 2005). For example, SARS-CoV (Rabenau et al. 2005) and MERS-CoV (Leclercq et al. 2014) can be quickly inactivated by exposing them to temperatures of 56-60 ${ }^{\circ} \mathrm{C}$ for $20-30 \mathrm{~min}$. On the other hand, storage at $4{ }^{\circ} \mathrm{C}$ does not have any effect on these CoVs (Rabenau et al. 2005; Lamarre and Talbot 1989). Notably, it has been reported that heating the samples at $56{ }^{\circ} \mathrm{C}$ for $30-60 \mathrm{~min}$, which is routinely performed before extracting the RNA for the PCR exams, effectively inactivates the virus (Pan et al. 2020).
Infectivity of SARS-CoV-2 in human tissues and reports of transmission by tissue and organ transplantation

The expression and distribution of hACE2 receptors in different human cells can be used to identify the potential routes of entry for the virus (Xu et al. 2020). Initially, Zou et al. (2020) identified the lung, heart, esophagus, kidney, bladder and ileum as organs that were at risk of SARS-CoV-2 infection, while type II alveolar cells, myocardial cells, renal proximal tubular cells and epithelial cells of the ileum, esophagus and bladder were classified as vulnerable targets of infection. Notably, new clinical conditions described in the literature indicate that the neurological (Mao et al. 2020) and hematological (Terpos et al. 2020) systems are also susceptible.

Several reports have identified hACE2 receptors in keratinocytes (Steckelings et al. 2004), fibroblasts (Steckelings et al. 2004), endothelial cells (Steckelings et al. 2004), osteoblasts (Kwok et al. 2012), osteoclasts (Kwok et al. 2012), retinal cells (White et al. 2015), and to a lesser extent in the cornea (White et al. 2015), conjunctiva (White et al. 2015) and sclera (White et al. 2015). Based on this receptor distribution, there is a potential risk that practically all transplanted tissues (i.e., skin, bones, cornea, conjunctiva, vessels and heart valves) could be contaminated with SARS-CoV-2, thus posing a serious risk of infection to the transplant recipients.

In a small cohort of 88 patients in an Italian hospital, skin manifestations such as skin rash, urticaria and vesicles, similar to typical lesions of acute viral conditions, were observed in 18 patients (Recalcati 2020). Moreover, in China, 12 out of 38 patients presented ophthalmological manifestations such as conjunctival hyperemia, chemosis, epiphora or increased secretion; and SARS-CoV-2 viral RNA was identified in the conjunctiva swab of two of these patients (Wu et al. 2020a, b). This latter observation is consistent with a previous study that showed coronaviruses can cause a variety of eye infections, including retinitis, uveitis and conjunctivitis (Seah and Agrawal 2020).

In amniotic membranes, the hACE2 receptor density is reduced when compared to other fetal membranes (Kalenga et al. 1996). However, despite the presence of hACE2 in the amniotic cells, there is still no evidence of vertical transmission of SARS-CoV-2. 
Indeed, two reports (Parazzini et al. 2020; Yu et al. 2020) failed to detect viral presence in the amniotic fluid and cord blood of newborns, using an rRT-PCR assay, thus making it impossible to confirm vertical transmission.

There are no reports of transmission of SARS-CoV or MERS-CoV through either transfusion or transplantation. However, these viruses were less widespread than SARS-CoV-2, and some transplant programs suspended activity during the outbreaks (Kates et al. 2020). Similarly, to date, there are no reports of SARS-CoV-2 transmission by tissue transplantation. Concerning organ transplantation and SARS-CoV-2, Hong et al. (2020) described a liver transplant case in which the donor was unknowingly infected, and the recipient was not infected. On the other hand, Lagana et al. (2020) reported that a donor and recipient tested positive for COVID-19 on the second and fourth postoperative days, respectively, following a living donor liver allograft procedure. In the liver biopsy, the recipient presented COVID-19 hepatitis, but the authors did not discuss the donorderived transmission.

Effect of tissue preservation and sterilization techniques on viral inactivation

The transplantation of allogeneic tissues carries an inherent risk of transmitting diseases to the recipient, especially those of contagious and infectious origin. In addition to quality assurance measures, tissue banks often employ tools such as strict donor screening, standardized operational procedures, microbiological and serological tests, processing methods, decontamination and sterilization to circumvent this problem (Narayan 2012). In case of virus, like HIV, hepatitis C and B, serological tests and Nucleic Acid Amplification Techniques (NAT) are essential to reduce the chance of contamination. On the other hand, less pathogenic viruses, like influenza or H1N1, should be evaluated with clinical history and PCR in pandemic situations (Chamorro et al. 2010). In Table 1, we summarize the main sterilization methods employed for tissue sterilization.

While conducting the present study, we were unable to identify any studies investigating the effect of processing and sterilization techniques on SARSCoV-2, specifically. However, since we expanded our search to include other coronaviruses, such as SARS and MERS, it was possible to retrieve several articles investigating the effects of refrigeration, freezing, lyophilization and gamma irradiation on these viruses. The results from these studies are summarized in Table 2.

\section{Refrigeration}

Refrigeration is a common technique utilized for conserving corneas and other ocular tissues (Patel et al. 2017), skin (Rosenquist et al. 1988) and some musculoskeletal tissues (Malinin et al. 2006). Typically, the collected tissue is transferred to saline or culture medium containing antibiotics and stored at $4{ }^{\circ} \mathrm{C}$.

While CoVs are usually quite sensitive to heat (Rabenau et al. 2005; Leclercq et al. 2014), especially at temperatures above $56{ }^{\circ} \mathrm{C}$, these viruses are not usually affected by low temperatures. For example, Rabenau et al. (2005) demonstrated that SARS-CoV maintains its infectivity capacity at $4{ }^{\circ} \mathrm{C}$ and another coronavirus, murine hepatitis virus (MHV-A59), was shown to remain stable for 3 months at $4{ }^{\circ} \mathrm{C}$ (Daniel and Talbot 1987). Additionally, Lamarre and Talbot (1989) investigated another member of the Coronoviradae family, $\mathrm{HCoV}-229 \mathrm{E}$, and found that it remains stable at $4{ }^{\circ} \mathrm{C}, \mathrm{pH}=6$. Based on the results from these studies, refrigeration alone cannot be considered an effective strategy for viral inactivation.

Another well-established conservation technique that uses refrigeration for tissue storage is glycerolation. Some tissue banks use this methodology for storing skin and amniotic membranes. Briefly, it involves exposing the tissue to high serial concentration glycerol baths ( $\geq 98 \%$ ), at $37{ }^{\circ} \mathrm{C}$ and then storing the tissue in a refrigerator for up to 2 years. Despite the $37{ }^{\circ} \mathrm{C}$ exposure, viral inactivation is dependent on both $\mathrm{pH}$ and exposure time. For example, MHV-A59 requires 14 days to become inactivated (Daniel and Talbot 1987). While MHV and SARS-CoV2 are $\beta$ CoVs that produce specific structural and accessory proteins, such as HE protein, $3 \mathrm{a} / \mathrm{b}$ protein, and $4 \mathrm{a} / \mathrm{b}$ protein (Mousavizadeh and Ghasemi 2020), the genomic similarity percentage is still unknown.

Although glycerol is produced in the gastrointestinal tract by lipid hydrolysis (Tao et al. 1983) and naturally present in various animal tissues, this polyalcohol is extremely toxic to cells when applied at high concentrations (Hoekstra et al. 1994). Herein, 
Table 1 Tissue sterilization methods

\begin{tabular}{|c|c|c|c|}
\hline Methods & Advantages & Disadvantages & Tissues \\
\hline Antibiotic soaks & Simple and low cost & Lack of complete tissue penetration & $\begin{array}{l}\text { Musculoskeletal/ } \\
\text { skin/cardiac } \\
\text { valves/cornea/amion }\end{array}$ \\
\hline $\begin{array}{l}\text { Ethylene oxide } \\
\text { gas }\end{array}$ & Inactive virus and bacterias & Toxic for cells & not used \\
\hline Peracetic acid & Good antimicrobial efficacy & $\begin{array}{l}\text { Reduced biomechanical strength of } \\
\text { tendons }\end{array}$ & Bone/skin/amnion \\
\hline Glycerol & Low cost and simple & $\begin{array}{l}\text { Lack of complete tissue } \\
\text { penetration/partial efficiency } \\
\text { against virus }\end{array}$ & Skin/amnion/cornea \\
\hline $\begin{array}{l}\text { Thermal } \\
\text { treatment with } \\
\text { moist heat }\end{array}$ & Preserve tensile strength of bone & Limited use & Femoral heads \\
\hline $\begin{array}{l}\text { Gamma } \\
\text { irradiation }\end{array}$ & $\begin{array}{l}\text { Safe, high penetration, sterilization in the final } \\
\text { package, not toxic, without temperature } \\
\text { alterations }\end{array}$ & $\begin{array}{l}\text { High doses can alter the biological } \\
\text { properties and mechanical function } \\
\text { of graft }\end{array}$ & $\begin{array}{l}\text { Skin/amnion } \\
\text { musculoskeletal }\end{array}$ \\
\hline
\end{tabular}

Table 2 Different human tissue processment and effect on inactivation of coronavirus

\begin{tabular}{|c|c|c|c|}
\hline Methods & Tissue & Viral inactivation & $\mathrm{CoV}$ inactivation \\
\hline Refrigeration & $\begin{array}{l}\text { Ocular tissue, musculoskeletal, } \\
\text { heart valve }\end{array}$ & Not inactive & Not inactive \\
\hline $\begin{array}{l}\text { Refrigeration } \\
\quad \text { (glicerolation) }\end{array}$ & Skin, amnion & Partially & No studies \\
\hline Freezing & $\begin{array}{l}\text { Musculoskeletal, heart valve, skin, } \\
\text { amnion, ocular tissue }\end{array}$ & Not inactive & Not inactive \\
\hline Chemical & Bone, skin & Partially & No studies in tissue \\
\hline Heat & Only bone (femoral head) & Inactive & No studies/good potential \\
\hline Lyophilization & Musculoskeletal, amnion, skin & $\begin{array}{l}\text { Could inactive if don't use } \\
\text { cryoprotectors during freezing }\end{array}$ & No studies \\
\hline $\begin{array}{l}\text { Gamma } \\
\text { iradiation }\end{array}$ & Skin, amnion, musculoskeletal & Good for RNA/DNA virus & $\begin{array}{l}\text { Inactive SARS and MERS/good } \\
\text { potential for SARS } 2\end{array}$ \\
\hline
\end{tabular}

we were unable to identify any studies investigating the effect of high glycerol concentrations on the inactivation of any type of CoV. Moreover, it is worth mentioning that despite being recognized as a potent virucide, glycerol was not fully effective at destroying the herpes simplex virus or poliovirus when incubated for 3 weeks at $20^{\circ} \mathrm{C}$ (Marshall et al. 1995). While there is some precedent in the literature, it is unclear whether or not this technique affords any protection against $\mathrm{CoV}$ contamination.

\section{Freezing}

Cryopreservation consists of maintaining tissues at either $-80^{\circ} \mathrm{C}$ (electric deep freezer) or $-180{ }^{\circ} \mathrm{C}$ (with liquid nitrogen). This type of preservation allows tissues to be stored for 3-5 years (Pegg 2006). Usually, this technique is used to preserve skeletal muscle tissue, skin and heart valves. Our literature review found that the infectious titer of $\mathrm{CoVs}$ is not affected by freezing and thawing. For example, MHVA59 and HCoV-229E can withstand 15 and 25 freeze/ thaw cycles, respectively (Lamarre and Talbot 1989; 
Daniel and Talbot 1987). Since there are no published studies on the effect of freezing on MERS and SARS infectivity, it is unknown how SARS-CoV-2 will respond to this technique. However, based on previous studies with other CoVs, it does not appear to be promising.

\section{Heat inactivation}

As alluded to above, CoVs are vulnerable to heat, and many laboratories have inactivated the virus in 30-60 min at $56-60{ }^{\circ} \mathrm{C}$ (Pan et al. 2020). In tissue banks, thermodisinfection is only used to decontaminate bone allografts (e.g., femoral heads) (Pruss et al. 2003, 2001), since the heat can damage and/or destroy the structure and quality of other tissues, like cartilage, menisci, corneal, skin, amnion and cardiovascular tissue (Pruss et al. 2010). It is important to point out that there are no studies about the inactivation of $\mathrm{CoVs}$ by heat in tissues.

\section{Disinfectants}

Recent studies (Kampf et al. 2020; Fathizadeh et al. 2020) have described the efficacy of disinfectants in inactivating CoVs on inanimate surfaces. For example, ethanol $(62-71 \%)$, hydrogen peroxide $(0.5 \%)$, sodium hypochloride $(0.1 \%)$, 2-propanol (70-75\%) and formaldehyde (1\%) have all successfully inactivated CoVs on surfaces. However, when applying disinfectants for tissue sterilization, a validated chemical procedure that maintains the acceptable therapeutic quality and preserves the biological properties of the tissue needs to be established (Pruss et al. 2010). Another risk associated with this technique is the presence of residual levels of disinfectant on a tissue (e.g., ethylene oxide), which can be toxic to the recipient (Kakiuchi et al. 1996). Furthermore, disinfectant-mediated viral inactivation cannot be used for corneal and cardiovascular tissue.

The use of peracetic acid $(0.1 \%$; with or without $96 \%$ ethanol) is a validated method for sterilizing bone (Mohr et al. 2016) and skin (Johnston et al. 2016). However, some virus is highly resistant to this treatment (Pruss et al. 2001). There are currently no reports about the efficacy of this technique on $\mathrm{CoV}$ inactivation in tissues.

\section{Lyophilization}

Lyophilization is a process in which a sample is first frozen, and then the solvent is removed by sublimation (primary drying) and desorption (secondary drying). This technique effectively inhibits both biological growth and chemical reactions. It is widely used for creating vaccines and is perhaps the most costeffective method for stabilizing infectious material (Florek et al. 2014). The cryoprotectants added during the freezing phase preserve the viral lipid membrane, and consequently, the infectivity of the virus even after the primary and secondary drying steps (Salvucci 2011). Indeed, Florek et al. (2014) demonstrated that lyophilized HCoV-NL63, which is responsible for airway infections, remained stable for 2 months at $4{ }^{\circ} \mathrm{C}$ and 14 days at room temperature.

Although it is not a sterilization method, reports show that lyophilization can inactivate viruses present in biological products (Unger et al. 2009; Kim et al. 2008). For example, there have been reports of HIV, hepatitis $\mathrm{B}(\mathrm{HBV})$ and $\mathrm{C}(\mathrm{HCV})$ transmission when transplanting frozen bones, yet no cases of transmission when lyophilized bones were utilized. It is important to point out that in the absence of cryoprotectant, the viral lipid membrane collapses after 4, 7 and 14 days for HCV, HIV and HBV, respectively, resulting in a subsequent loss of infectivity. In this sense, lower doses of complementary irradiation would be required for tissue sterilization (Salvucci 2011).

Studies investigating lyophilization-mediated $\mathrm{CoV}$ inactivation are virtually nonexistent. In fact, the only research on the topic was carried out by Rabenau et al. (2005), who evaluated and compared the inactivation mechanisms of SARS-CoV with HCoV-229E, adenovirus type 3 and HSV-1. Initially, the strains were frozen at $-80{ }^{\circ} \mathrm{C}$, cryopreservatives were then added after thawing, and $500 \mu \mathrm{l}$ of viral suspension was spread over a Petri dish and allowed to dry at room temperature. After 9 days, SARS-CoV was the last to lose its infectivity. While the results are interesting and relevant, the process used in this experiment is quite different from that performed in bone lyophilization. Given the limited number of studies on lyophilization and $\mathrm{CoVs}$, it remains unclear if this technique can inactivate these viruses. 


\section{Gamma irradiation}

Gamma irradiation is considered a sterilization method that is highly efficient at inactivating microorganisms. It produces small increases in temperature with good penetrability. This technique can also be carried out with the packaged tissue, thus avoiding recontamination upon repackaging. Additionally, it does not leave residues, produce polluting gases or generate radioactive products. On the other hand, high doses of ionizing radiation can damage the mechanical and histopathological structures, which can compromise the biological properties of the tissue (Yang et al. 2019).

Terminal sterilization of human allograft tissue using a low dose of gamma radiation was shown to inactivate both enveloped and non-enveloped viruses containing either RNA or DNA, reaching a sterility assurance level (SAL) of $10^{-6}$, which is a probability of not more than one viable microorganism in an amount of one million sterilized items of the final product. (Moore 2012). While there are currently no studies assessing the inactivation of SARS-CoV-2 by gamma radiation for tissue sterilization, studies with SARS-CoV and MERS have been conducted by researches in laboratory procedures.

For example, Kumar et al. (2015) completely inactivated a $10 \log _{10}$ MERS-CoV stock with a $20 \mathrm{kGy}$ dose from a Cobalt-60 source. The authors claimed that a $30 \mathrm{kGy}$ dose could sufficiently inactivate MERS-CoV in most cell culture laboratories. In another study, Feldmann et al. (2019) tested the effect of gamma irradiation on five emerging viruses, including SARS-CoV, and assessed their ability to invade Vero cells. It was found that SARS-CoV only required a $10 \mathrm{kGy}$ dose, which turned out to be the lowest required dose for inactivation, among the viruses evaluated. Since SARS-COV has the largest genome and required the lowest dose of radiation for viral inactivation, the authors speculated that the required radiation dose is inversely proportional to the size of the viral genome. Due to the small size of the SARS-CoV-2 genome, it is plausible that low doses of gamma irradiation could effectively inactivate the new virus, consequently inflicting less tissue damage. Despite these promising results, it is necessary to emphasize that all the studies performed thus far are experimental.
Among the available techniques, gamma irradiation appears to be the most promising approach for inactivating SARS-Cov-2. If proven effective in the clinical setting, tissue banks could offer greater safety to recipients of skin, amniotic membranes and bone allografts. However, more rigorous experimental studies will need to be undertaken so that the efficacy can be confirmed, and the minimum irradiation dose for SARS-CoV-2 inactivation can be determined in tissues. However, it should be stressed that this procedure cannot be used for corneal and cardiovascular tissue, or for meniscus and cartilage since the radiation can alter and perturb the biomechanical and histological properties of the tissue (Pruss et al. 2010).

\section{Conclusion}

Little is known about SARS-CoV-2 infecting human tissue. We recommend that tissue banks follow the specific health guidelines established in each country or region. Due to the limited information on physical and chemical methods of viral neutralization available at this time, rigorous donor screening and selection criteria are essential for tissue transplant recipient safety. Along these lines, we encourage that all donors undergo a SARS-CoV-2 PCR test before tissue donation to reduce the risk of viral transmission.

Among the processing and sterilization methods evaluated, we identified gamma irradiation as having the highest potential for guaranteeing the safety of patients receiving skin, amniotic membranes and bone transplants. While we expect that an irradiation dose between 20 and $30 \mathrm{kGy}$ will be effective at inactivating SARS-CoV-2, future studies will need to be performed for determining the exact values. On the other hand, donated heart valves and eye tissues, which are not usually irradiated, will need to be subjected to extensive screening and selection.

Furthermore, since SARS-CoV-2 is capable of circulating throughout the population long before the first case is officially detected (Zehender et al. 2020), gamma irradiation could be utilized to sterilize previously packaged tissues, potentially rescuing valuable tissue collected before the disease was officially confirmed in the region of the tissue bank. 
Author's contributions All authors participated in the design of the study, interpretation of the results, analysis of the data and review of the manuscript.

Funding This research received no specific grant from any funding agency in the public, commercial, or not-for-profit sectors.

\section{Compliance with ethical standards}

Conflict of interest The author(s) declared no potential conflicts of interest with respect to the research, authorship, and/or publication of this article.

\section{References}

Ashford P (2010) Traceability. Cell Tissue Bank 11:329-333. https://doi.org/10.1007/s10561-010-9195-3

Chamorro C, Palencia E, Bodí MA, Garrido G (2010) Valoración del potencial donante de órganos y tejidos en el seno de la pandemia por gripe A H1N1. Med Intens 34:127-133. https://doi.org/10.1016/j.medin.2009.11.001

Chang L, Yan Y, Wang L (2020) Coronavirus disease 2019: coronaviruses and blood safety. Transfus Med Rev 34(2):75-80. https://doi.org/10.1016/j.tmrv.2020.02.003

Chen J (2020) Pathogenicity and transmissibility of 2019-nCoV - a quick overview and comparison with other emerging viruses. Microbes Infect 22:69-71. https://doi. org/10.1016/j.micinf.2020.01.004

Cong Y, Kriegenburg F, De Haan CAM, Reggiori F (2017) Coronavirus nucleocapsid proteins assemble constitutively in high molecular oligomers. Sci Rep 7:5740. https://doi. org/10.1038/s41598-017-06062-w

Daniel C, Talbot PJ (1987) Physico-chemical properties of murine hepatitis virus, strain A 59. Brief Rep Arch Virol 96:241-248. https://doi.org/10.1007/bf01320963

Du R-H, Liang L-R, Yang C-Q et al (2020) Predictors of mortality for patients with COVID-19 pneumonia caused by SARS-CoV-2: a prospective cohort study. Eur Respir J 55(5):2000524. https://doi.org/10.1183/13993003.005242020

Fathizadeh H, Maroufi P, Momen-Heravi M et al (2020) Protection and disinfection policies against SARS-CoV-2 (COVID-19). Le Infez Med 28:185-191

Feldmann F, Shupert WL, Haddock E et al (2019) Gamma irradiation as an effective method for inactivation of emerging viral pathogens. Am J Trop Med Hyg 100:1275-1277. https://doi.org/10.4269/ajtmh.18-0937

Florek D, Burmistrz M, Potempa J, Pyrc K (2014) Stability of infectious human coronavirus NL63. J Virol Methods 205:87-90. https://doi.org/10.1016/j.jviromet.2014.04.001

Hoekstra MJ, Kreis RW, du Pont JS (1994) History of the Euro Skin Bank: the innovation of preservation technologies. Burns 20(Suppl 1):S43-S47

Hong H, Kim S, Choi DL, Kwon HH (2020) A case of coronavirus disease 2019 — infected liver transplant donor. Am J Transpl. https://doi.org/10.1111/ajt.15997.10.1111/ajt. 15997
Johnston C, Callum J, Mohr J et al (2016) Disinfection of human skin allografts in tissue banking: a systematic review report. Cell Tissue Bank 17:585-592

Kakiuchi M, Ono K, Nishimura A, Shiokawa H (1996) Preparation of bank bone using defatting, freeze-drying and sterilisation with ethylene oxide gas. Part 1. Experimental evaluation of its efficacy and safety. Int Orthop 20:142-146. https://doi.org/10.1007/s002640050051

Kalenga MK, Thomas K, De Gasparo M, De Hertogh R (1996) Determination of renin, angiotensin converting enzyme and angiotensin II levels in human placenta, chorion and amnion from women with pregnancy induced hypertension. Clin Endocrinol (Oxf) 44:429-433. https://doi.org/ 10.1046/j.1365-2265.1996.703525.x

Kampf G, Todt D, Pfaender S, Steinmann E (2020) Persistence of coronaviruses on inanimate surfaces and their inactivation with biocidal agents. J Hosp Infect 104:246-251

Kates OS, Fisher CE, Rakita RM et al (2020) Use of SARSCoV-2 infected deceased organ donors: Should we always “just say no?". Am J Transpl 20(7):1787-1794. https://doi. org/10.1111/ajt.16000

Kim IS, Choi YW, Kang Y et al (2008) Dry-heat treatment process for enhancing viral safety of an antihemophilic factor VIII concentrate prepared from human plasma. J Microbiol Biotechnol 18:997-1003

Kumar M, Mazur S, Ork BL et al (2015) Inactivation and safety testing of Middle East Respiratory Syndrome Coronavirus. J Virol Methods 223:13-18. https://doi.org/10.1016/j. jviromet.2015.07.002

Kwok T, Leung J, Zhang YF et al (2012) Does the use of ACE inhibitors or angiotensin receptor blockers affect bone loss in older men? Osteoporos Int 23:2159-2167. https://doi. org/10.1007/s00198-011-1831-7

Lagana SM, De Michele S, Lee MJ et al (2020) COVID-19 associated hepatitis complicating recent living donor liver transplantation. Arch Pathol Lab Med 144(8):929-932. https://doi.org/10.5858/arpa.2020-0186-sa

Lamarre A, Talbot PJ (1989) Effect of $\mathrm{pH}$ and temperature on the infectivity of human coronavirus 229E. Can J Microbiol 35:972-974. https://doi.org/10.1139/m89-160

Lauer SA, Grantz KH, Bi Q et al (2020) The incubation period of coronavirus disease 2019 (COVID-19) from publicly reported confirmed cases: estimation and application. Ann Intern Med 172(9):577-582. https://doi.org/10.7326/m200504

Leclercq I, Batéjat C, Burguière AM, Manuguerra JC (2014) Heat inactivation of the Middle East respiratory syndrome coronavirus. Influenza Other Respi Viruses 8:585-586. https://doi.org/10.1111/irv.12261

Malinin T, Temple HT, Buck BE (2006) Transplantation of osteochondral allografts after cold storage. J Bone Jt Surg Ser A 88:762-770. https://doi.org/10.2106/JBJS.D.02991

Mao L, Jin H, Wang M et al (2020) Neurologic manifestations of hospitalized patients with coronavirus disease 2019 in Wuhan, China. JAMA Neurol 77(6):683-690. https://doi. org/10.1001/jamaneurol.2020.1127

Marshall L, Ghosh MM, Boyce SG et al (1995) Effect of glycerol on intracellular virus survival: implications for the clinical use of glycerol-preserved cadaver skin. Burns 21:356-361 
Mohr J, Germain M, Winters M et al (2016) Disinfection of human musculoskeletal allografts in tissue banking: a systematic review. Cell Tissue Bank 17:573-584

Moore MA (2012) Inactivation of enveloped and non-enveloped viruses on seeded human tissues by gamma irradiation. Cell Tissue Bank 13:401-407. https://doi.org/10.1007/ s10561-011-9266-0

Mousavizadeh L, Ghasemi S (2020) Genotype and phenotype of COVID-19: their roles in pathogenesis. J Microbiol Immunol Infect. https://doi.org/10.1016/j.jmii.2020.03. 022

Narayan RP (2012) Development of tissue bank. Indian J Plast Surg 45:396-402. https://doi.org/10.4103/0970-0358. 101326

Nie J, Li Q, Wu J et al (2020) Establishment and validation of a pseudovirus neutralization assay for SARS-CoV-2. Emerg Microbes Infect 9:680-686. https://doi.org/10.1080/ 22221751.2020.1743767

Pan Y, Long L, Zhang D et al (2020) Potential false-negative nucleic acid testing results for severe acute respiratory syndrome coronavirus 2 from thermal inactivation of samples with low viral loads. Clin Chem. 66(6):794-801. https://doi.org/10.1093/CLINCHEM/HVAA091

Parazzini F, Bortolus R, Mauri PA et al (2020) Delivery in pregnant women infected with SARS-CoV-2: a fast review. Int J Gynaecol Obstet 150(1):41-46. https://doi. org/10.1002/ijgo.13166

Patel D, Tandon R, Ganger A et al (2017) Study of death to preservation time and its impact on utilisation of donor corneas. Trop Doct 47:365-370. https://doi.org/10.1177/ 0049475517713406

Pegg DE (2006) The preservation of tissues for transplantation. Cell Tissue Bank 7:349-358. https://doi.org/10.1007/ s10561-006-9013-0

Pruss A, Hansen A, Kao M et al (2001) Comparison of the efficiacy of virus inactivation methods in allogeneic avital bone tissue transplants. Cell Tissue Bank 2:201-215

Pruss A, Kao M, Von Garrel T et al (2003) Virus inactivation in bone tissue transplants (femoral heads) by moist heat with the "Marburg bone bank system". Biologicals 31:75-82. https://doi.org/10.1016/S1045-1056(02)00095-7

Pruss A, Caspari G, Krüger DH et al (2010) Tissue donation and virus safety: more nucleic acid amplification testing is needed. Transpl Infect Dis 12:375-386. https://doi.org/10. 1111/j.1399-3062.2010.00505.x

Rabenau HF, Cinatl J, Morgenstern B et al (2005) Stability and inactivation of SARS coronavirus. Med Microbiol Immunol 194:1-6. https://doi.org/10.1007/s00430-004-0219-0

Recalcati S (2020) Cutaneous manifestations in COVID-19: a first perspective. J Eur Acad Dermatol Venereol 34(5):e212-e213. https://doi.org/10.1111/jdv.16387

Rosenquist MD, Cram AE, Kealey GP (1988) Short-term skin preservation at $4{ }^{\circ} \mathrm{C}$ : skin storage configuration and tissueto-volume medium ratio. J Burn Care Rehabil 9:52-54. https://doi.org/10.1097/00004630-198801000-00012

Salvucci JT (2011) Bone tissue, lyophilized and stored at room temperature for 15 days or more, is not capable of transmitting HIV, HCV or HBV. Cell Tissue Bank 12:99-104. https://doi.org/10.1007/s10561-010-9173-9

Seah I, Agrawal R (2020) Can the coronavirus disease 2019 (COVID-19) affect the eyes? A review of coronaviruses and ocular implications in humans and animals. Ocul Immunol Inflamm 28(3):391-395. https://doi.org/10.1080/ 09273948.2020.1738501

Steckelings UM, Wollschläger T, Peters J et al (2004) Human skin: source of and target organ for angiotensin II. Exp Dermatol 13:148-154. https://doi.org/10.1111/j.09066705.2004.0139.x

Tao RC, Kelley RE, Yoshimura NN, Benjamin F (1983) Glycerol: its metabolism and use as an intravenous energy source. J Parenter Enter Nutr 7:479-488. https://doi.org/10. 1177/0148607183007005479

Terpos E, Ntanasis-Stathopoulos I, Elalamy I et al (2020) Hematological findings and complications of COVID-19. Am J Hematol 95(7):834-847. https://doi.org/10.1002/ajh. 25829

Unger U, Poelsler G, Modrof J, Kreil TR (2009) Virus inactivation during the freeze-drying processes as used for the manufacture of plasma-derived medicinal products. Transfusion 49:1924-1930. https://doi.org/10.1111/j. 1537-2995.2009.02218.x

Wang Q, Zhang Y, Wu L et al (2020) Structural and functional basis of SARS-CoV-2 entry by using human ACE2. Cell 181(4):894-904.e9. https://doi.org/10.1016/j.cell.2020.03. 045

Weston S, Frieman MB (2020) COVID-19: knowns, unknowns, and questions. mSphere 5(2):e00203-e220. https://doi.org/ 10.1128/msphere.00203-20

White AJR, Cheruvu SC, Sarris M et al (2015) Expression of classical components of the renin-angiotensin system in the human eye. J Renin Angiotensin Aldosterone Syst 16:59-66. https://doi.org/10.1177/1470320314549791

Wu D, Wu T, Liu Q, Yang Z (2020a) The SARS-CoV-2 outbreak: what we know. Int J Infect Dis 94:44-48. https://doi. org/10.1016/j.ijid.2020.03.004

Wu P, Duan F, Luo C et al (2020b) Characteristics of ocular findings of patients with coronavirus disease 2019 (COVID-19) in Hubei Province. China JAMA Ophthalmol 138(5):575-578. https://doi.org/10.1001/jamaophthalmol. 2020.1291

Xu H, Zhong L, Deng J et al (2020) High expression of ACE2 receptor of 2019-nCoV on the epithelial cells of oral mucosa. Int J Oral Sci 12(1):8. https://doi.org/10.1038/ s41368-020-0074-X

Yang X, Feng J, Wang F, Hu Y (2019) Irradiation sterilization used for allogenetic tendon: a literature review of current concept. Cell Tissue Bank 20:129-139. https://doi.org/10. 1007/s10561-019-09756-9

Yu X, Yang R (2020) COVID-19 transmission through asymptomatic carriers is a challenge to containment. Influenza Other Respi Viruses 14(4):474-475. https://doi. org/10.1111/irv.12743

Yu N, Li W, Kang Q et al (2020) Clinical features and obstetric and neonatal outcomes of pregnant patients with COVID19 in Wuhan, China: a retrospective, single-centre, descriptive study. Lancet Infect Dis 20(5):559-564. https:// doi.org/10.1016/s1473-3099(20)30176-6

Zehender G, Lai A, Bergna A et al (2020) Genomic characterisation and phylogenetic analysis of SARS-CoV-2 in Italy. J Med Virol. https://doi.org/10.1002/jmv.25794

Zou X, Chen K, Zou J et al (2020) Single-cell RNA-seq data analysis on the receptor ACE2 expression reveals the 
potential risk of different human organs vulnerable to 2019-nCoV infection. Front Med 14(2):185-192. https:// doi.org/10.1007/s11684-020-0754-0
Publisher's Note Springer Nature remains neutral with regard to jurisdictional claims in published maps and institutional affiliations. 